\title{
Thermal modification of activated carbon surface chemistry improves its capacity as redox mediator for azo dye reduction
}

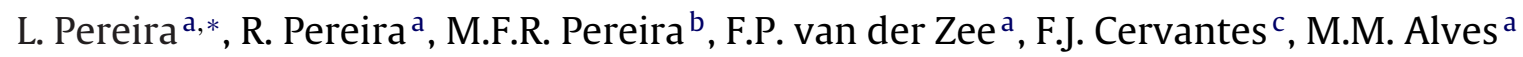 \\ a Instituto Biotecnologia e Bioengenharia (IBB), Centro Engenharia Biológica, Universidade do Minho, Campus de Gualtar, $4710-057$ Braga, Portugal

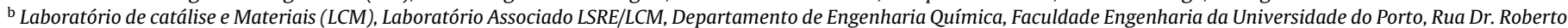 \\ Frias, 4200-465 Porto, Portugal

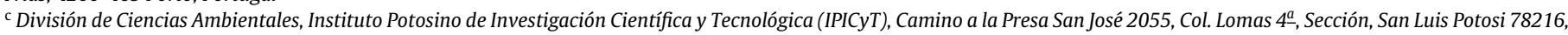 \\ Mexico
}

\section{A R T I C L E I N F O}

\section{Article history:}

Received 31 May 2010

Received in revised form 20 July 2010

Accepted 2 August 2010

Available online 7 August 2010

\section{Keywords:}

Activated carbon

Redox mediator

Azo dye

Reduction

Decolourisation

\begin{abstract}
A B S T R A C T
The surface chemistry of a commercial $A C\left(\mathrm{AC}_{0}\right)$ was selectively modified, without changing significantly its textural properties, by chemical oxidation with $\mathrm{HNO}_{3}\left(\mathrm{AC}_{\mathrm{HNO}_{3}}\right)$ and $\mathrm{O}_{2}\left(\mathrm{AC}_{\mathrm{O}_{2}}\right)$, and thermal treatments under $\mathrm{H}_{2}\left(\mathrm{AC}_{\mathrm{H}_{2}}\right)$ or $\mathrm{N}_{2}\left(\mathrm{AC}_{\mathrm{N}_{2}}\right)$ flow. The effect of modified $\mathrm{AC}$ on anaerobic chemical dye reduction was assayed with sulphide at different pH values 5, 7 and 9. Four dyes were tested: Acid Orange 7, Reactive Red 2, Mordant Yellow 10 and Direct Blue 71. Batch experiments with low amounts of $\mathrm{AC}\left(0.1 \mathrm{~g} \mathrm{~L}^{-1}\right)$ demonstrated an increase of the first-order reduction rate constants, up to 9-fold, as compared with assays without AC. Optimum rates were obtained at $\mathrm{pH} 5$ except for MY10, higher at $\mathrm{pH}$ 7. In general, rates increased with increasing the $\mathrm{pH}$ of point zero charge $\left(\mathrm{pH}_{\mathrm{pzc}}\right)$, following the trend $\mathrm{AC}_{\mathrm{HNO}_{3}}<\mathrm{AC}_{\mathrm{O}_{2}}<\mathrm{AC}_{0}<\mathrm{AC}_{\mathrm{N}_{2}}<\mathrm{AC}_{\mathrm{H}_{2}}$. The highest reduction rate was obtained for MY10 with $\mathrm{AC}_{\mathrm{H}_{2}}$ at $\mathrm{pH}$ 7, which corresponded to the double, as compared with non-modified $\mathrm{AC}$. In a biological system using granular biomass, $\mathrm{AC}_{\mathrm{H}_{2}}$ also duplicated and increase 4.5-fold the decolourisation rates of MY10 and RR2, respectively. In this last experiment, reaction rate was independent of AC concentration in the tested range $0.1-0.6 \mathrm{~g} \mathrm{~L}^{-1}$.
\end{abstract}

(c) 2010 Elsevier B.V. All rights reserved.

\section{Introduction}

Azo groups are the most common chromophore in acid, direct and dispersive dyes and are also frequently used as components in reactive dyes. Their industrial applications include the use as textiles dyes, leather, colouring agents in food and in pharmaceuticals, cosmetics and paper. Their environmental impact either as pollutants or carcinogens is of major concern [1]. As very small amounts of synthetic dyes in water (10-15 $\mathrm{mg} \mathrm{L}^{-1}$ ) are highly visible, they also have an undesirable aesthetic impact. Dye removal from wastewater with traditional physicochemical processes, such as coagulation, adsorption and oxidation with ozone is expensive, can generate large volumes of sludge and usually require the addition of environmental hazardous chemical additives [2]. Azo dyes are generally persistent under aerobic conditions because oxygen is a more efficient electron acceptor, therefore having more preference for electrons than azo dyes [3]. Under anaerobic conditions most azo dyes are reduced, although the rate of the reaction may be rather low, especially for dyes with high polarity or complicated structure, such as some sulphonated reactive azo dyes. This poses a serious

\footnotetext{
* Corresponding author. Tel.: +351253604 420.

E-mail address: lucianapereira@deb.uminho.pt (L. Pereira).
}

problem for the application of high-rate anaerobic bioreactors for the treatment of dying wastewater, because long hydraulic retention time is necessary to reach a satisfactory extent of dye reduction. Enzyme cofactors like FAD are known as effective redox mediators for azo dye reduction [4]. Moreover, addition of compounds, usually exemplified by soluble quinone compounds, has also been proved to significantly accelerate the rate of azo dye reduction by favouring electron transfer from primary electron donor (co-substrate) to terminal electron acceptor (azo dye). Among them, anthraquinonedisulphonate (AQDS) and anthraquinone-2sulphonate (AQS), as model quinonoid compounds, have received the greatest attention [5,6]. Using these redox mediators, higher reductive efficiency can be achieved in anaerobic bioreactors, operated at hydraulic retention time realistic for wastewater treatment practice $[6,7,9]$. However, the main problem limiting their application in anaerobic bioreactors is that continuous dosing implies continuous expenses of mediator as well as continuous discharge of this kind of biologically recalcitrant compound. Activated carbon (AC) has been shown as a feasible redox mediator $[10,11]$. An important advantage in comparison with soluble redox mediators is that it can be retained within the sludge bed. Furthermore, its amphoteric character enables to manifest reactivity for many organic and inorganic pollutants. Adsorption on AC has also been proved to be efficient in removing colour and organic matter from highly 
<smiles>O=S(=O)(O[Na])c1ccc(N=Nc2c(O)ccc3ccccc23)cc1</smiles>

Acid Orange 7 (AO7)<smiles>O=[N+]([O-])c1cc(Nc2nc(Cl)nc(Cl)n2)c2c(O)c(N=Nc3ccccc3)c([N+](=O)[O-])cc2c1</smiles>

Reactive Red 2 (RR2)<smiles>O=C(O)c1cc(/N=N/c2ccc(S(=O)(=O)O[Na])cc2)ccc1O</smiles>

Mordant yellow 10 (MY10)<smiles>Nc1ccc2c(O)c(N=Nc3ccc(N=Nc4ccc(N=Nc5cc([N+](=O)[O-])c6cccc(S(N)(=O)=O)c6c5)c5ccccc45)c4c3CC([S+]([O])(=O)O[Na])=CC4)c([N+](=O)[O-])cc2c1</smiles>

Direct Blue 71 (DB71)

Fig. 1. Molecular structure of the azo dyes.

coloured effluents [12-16]. Some publications outline the use of $\mathrm{AC}$ as a catalyst in chemical reactions: oxidative dehydrogenation of ethylbenzene [16], $\mathrm{NO}$ and $\mathrm{N}_{2} \mathrm{O}$ reduction [18,19], reduction of 2,4,6-trinitrotoluene [20] and decomposition of methane [21]. Other advantage of $A C$ is that it can be modified physically and chemically, in order to optimise its performance. The effect of AC chemical surface on dye adsorption was previously studied $[12,22,23]$, and very recently Mezohegyi et al. [24] found that decolourisation rates, in upflow stirred packed-bed reactors, were significantly influenced by the textural properties of AC and moderately affected by its surface chemistry. However, these authors performed experiments in reactors with working volumes of $2 \mathrm{~mL}$ and $500 \mathrm{~g} \mathrm{AC} \mathrm{L}^{-1}$, which is too far from potential applicability.

In the present work, the redox mediating capacity of AC samples with different chemical superficial groups was explored in batch assays for the reduction of four azo dyes (acid, direct, mordant and reactive), at different $\mathrm{pH}$ values. Since sulphate is a common pollutant present in textile wastewater being biologically reduced to sulphide, during anaerobic treatment and sulphide has been reported to be an azo dye reducing agent [25,26], sulphide was initially elected as chemical reducing agent. This choice was also based on its suitability to limit the system variability. AC samples were obtained by chemical/thermal treatments of a commercial AC. Biological assays were performed in the best conditions obtained by the chemical dye reduction studies. Activated carbon was mixed with anaerobic granular sludge at final concentrations in the range of $0.1-0.6 \mathrm{~g} \mathrm{~L}^{-1}$.

\section{Experimental}

\subsection{Dyes}

Reactive Red 2 (RR2, dye content 40\%), Acid Orange 7 (AO7, dye content 85\%), Mordant Yellow 10 (MY10, dye content 85\%) and
Direct Blue 71 (DB71, dye content 50\%), were selected as azo dye model compounds. The chemical structures of the dyes are illustrated in Fig. 1. Dyes were purchased from Sigma and used without additional purification. Stock solutions of $14 \mathrm{mM}$ were prepared in deionised water. RR2 was hydrolysed under alkaline conditions ( $\mathrm{pH}$ 12 adjusted with $1 \mathrm{M} \mathrm{NaOH}$ ) by boiling the solution for $1 \mathrm{~h}$; after that period, solution was cooled down, $\mathrm{pH}$ was settled to 7 with $1 \mathrm{M} \mathrm{HCl}$ and final volume adjusted with deionised water.

\subsection{Preparation of activated carbon samples}

A Norit ROX 0.8 activated carbon (pellets of $0.8 \mathrm{~mm}$ diameter and $5 \mathrm{~mm}$ length) was used as supplied by Norit as a starting material (sample $\mathrm{AC}_{0}$ ). In order to prepare $\mathrm{AC}$ with different chemical composition on the surface, maintaining the original textural properties as much as possible, different treatments were performed according to those previously described by Pereira et al. [12], as following: (i) chemical oxidation of $\mathrm{AC}_{0}$ with $6 \mathrm{M}$ of $\mathrm{HNO}_{3}$ at boiling temper-

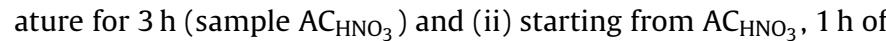
thermal treatment under $\mathrm{N}_{2}$ flow at $900{ }^{\circ} \mathrm{C}$ (sample $\mathrm{AC}_{\mathrm{N}_{2}}$ ) or $\mathrm{H}_{2}$ flow at $700{ }^{\circ} \mathrm{C}$ (sample $\mathrm{AC}_{\mathrm{H}_{2}}$ ). Gas oxidation of $\mathrm{AC}_{0}$ with $5 \% \mathrm{O}_{2}$ at $425^{\circ} \mathrm{C}$ for $6 \mathrm{~h}$ was made in order to prepare the sample $\mathrm{AC}_{\mathrm{O}_{2}}$; in this case, some burning of the sample occurred (12.5\%) which will result in alteration of the textural properties [26].

\subsection{Textural characterisation of activated carbons}

The textural characterisation of the materials was based on $\mathrm{N}_{2}$ adsorption isotherms, determined at $77 \mathrm{~K}$ with a Coulter Omnisorp $100 \mathrm{CX}$ apparatus. The BET surface area $\left(S_{\mathrm{BET}}\right)$ was calculated using the BET equation. The micropore volume $\left(W_{\text {micro }}\right)$ and mesopore surface area $\left(S_{\text {meso }}\right)$ were calculated by the $t$-method, using the standard isotherms for carbon materials proposed by RodriguezReinoso et al. [28]. The adsorption data were also analysed with the 
Dubinin equation. In all cases, a type IV deviation was noted [29]. Two microporous structures were taken into account, and the corresponding volumes, $W_{01}$ (smaller pores) and $W_{02}$ (larger pores), were calculated [29]. The Stoeckli equation [30] was used to estimate the average micropore width of the smaller pores $\left(L_{1}\right)$, using a value of 0.34 for the affinity coefficient of nitrogen.

\subsection{Surface chemistry characterisation of activated carbons}

Activated carbon samples have amphoteric behaviour and in general the more acidic samples are the less basic ones. Acidity and basicity are related with the chemical groups at the AC surface; the surface chemistry of AC samples was characterised by the estimation of material acidity and basicity, the $\mathrm{pH}$ of point zero charge $\left(\mathrm{pH}_{\mathrm{pzc}}\right)$ and $\mathrm{CO} / \mathrm{CO}_{2}$ release by temperature-programmed desorption (TPD) as described by Figueiredo et al. [27,31]. Briefly:

(i) The $\mathrm{CO}_{2}$ spectrum was decomposed into three contributions, corresponding to carboxylic acids (low temperatures), carboxylic anhydrides (intermediate temperatures) and lactones (high temperatures).

(ii) The carboxylic anhydrides decompose by releasing one $\mathrm{CO}$ and one $\mathrm{CO}_{2}$ molecule. Thus, a peak of the same shape and equal magnitude to that found on the $\mathrm{CO}_{2}$ spectrum was included in $\mathrm{CO}$ spectrum. This peak was pre-defined from the deconvolution of the $\mathrm{CO}_{2}$ spectrum.

(iii) In addition to the carboxylic anhydrides, the $\mathrm{CO}$ spectrum includes contributions from phenols (intermediate temperatures) and carbonyl/quinones (high temperatures).

The $\mathrm{pH}_{\mathrm{pzc}}$ is a critical value for determining quantitatively the net charge (positive or negative) carried on the AC surface as a function of the solution $\mathrm{pH}$. Its determination was carried out as follows: $50 \mathrm{~cm}^{3}$ of $0.01 \mathrm{M} \mathrm{NaCl}$ solution was placed in a closed Erlenmeyer flask. The $\mathrm{pH}$ was adjusted to a value between 2 and 12 with the solutions $0.1 \mathrm{M} \mathrm{HCl}$ or $0.1 \mathrm{M} \mathrm{NaOH}$. Then, $0.15 \mathrm{~g}$ of each AC sample was added and the final $\mathrm{pH}$ measured after $48 \mathrm{~h}$ under agitation at room temperature. The $\mathrm{pH}_{\mathrm{pzc}}$ is the point where the curve $\mathrm{pH}_{\text {final }}$ vs. $\mathrm{pH}_{\text {initial }}$ crosses the line $\mathrm{pH}_{\text {initial }}=\mathrm{pH}_{\text {final }}$.

\subsection{Chemical dye reduction}

Batch experiments were conducted in order to evaluate the capacity of the synthesised AC samples as a redox mediator on the reduction of different azo dyes by sulphide. Buffered solutions at different pH values, $20 \mathrm{mM}$ of sodium acetate for $\mathrm{pH} 5.0$ and $60 \mathrm{mM}$ sodium bicarbonate for $\mathrm{pH} 7.0$ and 8.7 , were prepared. AC pellets were crushed to obtain particles with different size. A preliminary screening showed that the size of AC particles significantly affects their role as a redox mediator for dye reduction by sulphide. An increase of the rate of decolourisation was obtained with decreasing the AC size. Therefore, all the experiments were conducted with AC particles with a diameter less than $0.315 \mathrm{~mm}$. The flasks, containing different samples of activated carbon $\left(0.1 \mathrm{~g} \mathrm{~L}^{-1}\right)$ and buffer, were sealed with butyl rubber stoppers and flushed for $5 \mathrm{~min}$ with oxygen-free $\mathrm{N}_{2}$ gas for $\mathrm{pH} 5.0$ and 8.7 and with $\mathrm{N}_{2}: \mathrm{CO}_{2}(80: 20 \%)$ for $\mathrm{pH}$ 7.0. After flushing, sulphide was added with a syringe from a partially neutralised stock solution $\left(0.1 \mathrm{M} \mathrm{Na}_{2} \mathrm{~S}\right)$ to obtain an initial total sulphide concentration of $1 \mathrm{mM}$ for azo and $2 \mathrm{mM}$ for trisazo dyes. According to the stoichiometry of dye reduction by sulphide, 2 moles of sulphide are required per mole of azo dye when sulphide is oxidised to elemental sulphur [10]. Controls without sulphide were incorporated to correct for dye adsorption, as well as to verify the stability of the dyes. The vials were pre-incubated (over night) in a $37^{\circ} \mathrm{C}$ rotary shaker at $135 \mathrm{rpm}$. After that time, $0.3 \mathrm{mM}$ of dye was added with a syringe $(1 \mathrm{~mL})$ to the reaction solution, from a concentrated stock $(14 \mathrm{mM})$. All the experiments were prepared in triplicate. First-order reduction rate constants were calculated in OriginPro 6.1 software, applying the equation $C_{t}=C_{\mathrm{o}}+C_{\mathrm{i}} e^{-k t}$, where $C_{t}$ is the concentration at time $t ; C_{0}$, the offset; $C_{i}$, the concentration at time initial time; $k$, the first-order rate constant $\left(\mathrm{d}^{-1}\right)$ and $t$ is the accumulated time of the experiment.

\subsection{Biological dye reduction}

Biological assays using anaerobic granular biomass $\left(1 \mathrm{~g} \mathrm{VSS} \mathrm{L}^{-1}\right)$ were performed in batch. The best conditions from the chemical dye reduction were reproduced: sodium bicarbonate solution at $\mathrm{pH} 7$ containing $0.3 \mathrm{mM}$ of MY10 and $0.1 \mathrm{~g} \mathrm{~L}^{-1}$ of $\mathrm{AC}_{\mathrm{H}_{2}}$. As controls, assays without $A C$ and with $A_{0}$ were also run. Co-substrates are required as an electron source for the reduction; different carbon sources were tested $\left(2 \mathrm{~g} \mathrm{~L}^{-1}\right)$ : glucose, lactose, and volatile fatty acids (VFAs): acetic, propionic and butyric acid, 1:10:10. As macronutrients, $2.8 \mathrm{~g} \mathrm{~L}^{-1} \mathrm{NH}_{4} \mathrm{Cl}, 2.5 \mathrm{~g} \mathrm{~L}^{-1} \mathrm{KH}_{2} \mathrm{PO}_{4}, 1 \mathrm{~g} \mathrm{~L}^{-1} \mathrm{MgSO}_{4} \cdot 7 \mathrm{H}_{2} \mathrm{O}$ and $0.057 \mathrm{~g} \mathrm{~L}^{-1} \mathrm{CaCl}$, were added. All the assays were performed in triplicate. The effect of $A C$ concentration was evaluated by testing increasing amounts of untreated $\left(\mathrm{AC}_{0}\right)$ and treated $\mathrm{AC}\left(\mathrm{AC}_{\mathrm{H}_{2}}\right)$ ranging from $0.1 \mathrm{~g} \mathrm{~L}^{-1}$ to $0.6 \mathrm{~g} \mathrm{~L}^{-1}$.

\subsection{Analytical techniques}

Colour decrease was monitored spectrophotometricaly in a 96well plate reader (ELISA BIO-TEK, Izasa). At select intervals, samples were withdrawn $(300 \mu \mathrm{L})$, centrifuged at $1500 \mathrm{rpm}$ for $10 \mathrm{~min}$ to remove the $\mathrm{AC}$ and diluted, with the same buffer as of the reaction, due to the high absorbance of the dye, even at low concentrations. The visible spectra $(300-900 \mathrm{~nm})$ were recorded and dye concentration calculated at $\lambda_{\max }$. Molar extinction coefficients were calculated for each dye at $\lambda_{\max }: \varepsilon_{480 \mathrm{~nm}}=9600 \mathrm{M}^{-1} \mathrm{~cm}^{-1}$ for AO7; $\varepsilon_{540 \mathrm{~nm}}=28,637 \mathrm{M}^{-1} \mathrm{~cm}^{-1}$ for RR2; $\varepsilon_{350 \mathrm{~nm}}=15,519 \mathrm{M}^{-1} \mathrm{~cm}^{-1}$ for MY10 and $\varepsilon_{590 \mathrm{~nm}}=76,716 \mathrm{M}^{-1} \mathrm{~cm}^{-1}$ for DB71. No changes were observed in the visible spectra with the $\mathrm{pH}$ of the solution.

\section{Results and discussion}

\subsection{Textural characterisation}

A set of modified AC samples were prepared by different methods in order to obtain materials with different surface chemical groups (acidic and basic) but maintaining their textural properties. The results of textural characterisation resulting from the $\mathrm{N}_{2}$ equilibrium adsorption isotherms at $77 \mathrm{~K}$ are presented in Table 1 . No

Table 1

Textural characterisation of the activated carbon samples.

\begin{tabular}{|c|c|c|c|c|c|c|}
\hline Sample & $\begin{array}{l}S_{\text {BET }}\left(\mathrm{m}^{2} \mathrm{~g}^{-1}\right) \\
( \pm 10)\end{array}$ & $\begin{array}{l}W_{\text {micro }}\left(\mathrm{cm}^{3} \mathrm{~g}^{-1}\right) \\
( \pm 0.005)\end{array}$ & $\begin{array}{l}S_{\text {meso }}\left(\mathrm{m}^{2} \mathrm{~g}^{-1}\right) \\
( \pm 5)\end{array}$ & $\begin{array}{l}W_{01}\left(\mathrm{~cm}^{3} \mathrm{~g}^{-1}\right) \\
( \pm 0.005)\end{array}$ & $\begin{array}{l}W_{02}\left(\mathrm{~cm}^{3} \mathrm{~g}^{-1}\right) \\
( \pm 0.005)\end{array}$ & $L_{1}(\mathrm{~nm})( \pm 0.1)$ \\
\hline $\mathrm{AC}_{0}$ & 1032 & 0.382 & 138 & 0.350 & 0.038 & 1.0 \\
\hline $\mathrm{AC}_{\mathrm{HNO}_{3}}$ & 893 & 0.346 & 102 & 0.309 & 0.032 & 1.0 \\
\hline $\mathrm{AC}_{\mathrm{O}_{2}}$ & 1281 & 0.497 & 149 & 0.450 & 0.045 & 1.2 \\
\hline $\mathrm{AC}_{\mathrm{N}_{2}}$ & 947 & 0.359 & 90.5 & 0.340 & 0.023 & 1.1 \\
\hline $\mathrm{AC}_{\mathrm{H}_{2}}$ & 987 & 0.377 & 129 & 0.334 & 0.039 & 1.1 \\
\hline
\end{tabular}


Table 2

Chemical characterisation of the activated carbon samples.

\begin{tabular}{|c|c|c|c|c|c|}
\hline Sample & $\mathrm{CO}^{\mathrm{a}}\left(\mu \mathrm{molg}^{-1}\right)( \pm 20)$ & $\mathrm{CO}_{2}{ }^{\mathrm{a}}\left(\mu \mathrm{molg}^{-1}\right)( \pm 20)$ & $\begin{array}{l}\left.\text { Basicity (mequiv. } \mathrm{HCl} \mathrm{g}^{-1}\right) \\
( \pm 0.005)\end{array}$ & $\begin{array}{l}\left.\text { Acidity (mequiv. } \mathrm{NaOH} \mathrm{g}^{-1}\right) \\
( \pm 0.005)\end{array}$ & $\mathrm{pH}_{\mathrm{pzc}}( \pm 0.2)$ \\
\hline $\mathrm{AC}_{0}$ & 814 & 243 & 0.457 & 0.370 & 8.4 \\
\hline $\mathrm{AC}_{\mathrm{HNO}_{3}}$ & 2402 & 1103 & -0.065 & 1.720 & 2.7 \\
\hline $\mathrm{AC}_{\mathrm{O}_{2}}$ & 4105 & 239 & n.d. & n.d. & 4.5 \\
\hline $\mathrm{AC}_{\mathrm{N}_{2}}$ & 890 & 120 & 0.547 & 0.432 & 9.2 \\
\hline $\mathrm{AC}_{\mathrm{H}_{2}}$ & 590 & 59 & 0.640 & 0.086 & 10.8 \\
\hline
\end{tabular}

n.d., not determined.

a Amounts release in TPD experiments.

major changes were observed in the textural properties of $\mathrm{AC}$ for the liquid phase oxidations and thermal treatments, as expected. However, a slight decrease occurred in the surface area and pore volume for the oxidation with $\mathrm{HNO}_{3}$. These changes may result from the collapse of some of the pore walls caused from the drastic conditions of the treatment. On the other hand, sample prepared by $\mathrm{O}_{2}$ oxidation presents an increase of the micropore volume and average micropore width. This effect is directly related with the burn-off (BO) degree [26]. Consequently, an additional contribution of the textural properties of $\mathrm{AC}$ on its behaviour as a catalyst on dye reduction may be expected for the last material. For the other AC samples, the behaviour may be attributed mainly to differences on the chemical surface properties produced by different treatments (see below).

\subsection{Surface chemistry characterisation}

Table 2 summarises the results obtained from the chemical characterisation of AC samples used in this study. Surface oxygen groups on carbon materials decompose upon heating, releasing $\mathrm{CO}$ and/or $\mathrm{CO}_{2}$ at different temperatures. According to this, it is possible to identify and estimate the amount of oxygenated groups on a given carbon by TPD experiments. Table 3 shows the amount of each type of oxygen-containing surface groups estimated from the deconvolution of the TPD spectra (Fig. 2) following the method previously proposed $[26,30]$. The highest amount of carboxylic groups was generated by the oxidation with $\mathrm{HNO}_{3}$, which presents a value almost 7 times higher than those generated with other treatments. Although to a lesser degree, this sample also presents the highest amount of anhydrides and lactones groups. These acidic groups are responsible for the high acidity and the lower $\mathrm{pH}_{\mathrm{pzc}}$ value obtained. In fact, the basicity and acidity of the samples are related with the chemical groups at the surface, thus complementing the results obtained from TPD experiments. Higher $\mathrm{CO}_{2}$ release was obtained for more acidic samples, $\mathrm{AC}_{\mathrm{HNO}_{3}}\left(\mathrm{pH}_{\mathrm{pzc}}\right.$ of 2.7) and $\mathrm{AC}_{\mathrm{O}_{2}}\left(\mathrm{pH}_{\mathrm{pzc}}\right.$ of 4.5) which indicates that liquid and gas oxidation produce samples with a higher amount of surface oxygen-containing groups. The gas oxidation treatment $\left(\mathrm{AC}_{\mathrm{O}_{2}}\right)$ was the most effective to introduce phenols and carbonyl/quinone groups, being almost the double when compared with the nitric acid treatment. Thermal treatments at high temperature produce materials with low amount of oxygencontaining groups and high basicity, resulting mainly from the ketonic groups remaining on the surface, from the low amount of acidic groups, and from the delocalised $\pi$-electrons of the carbon
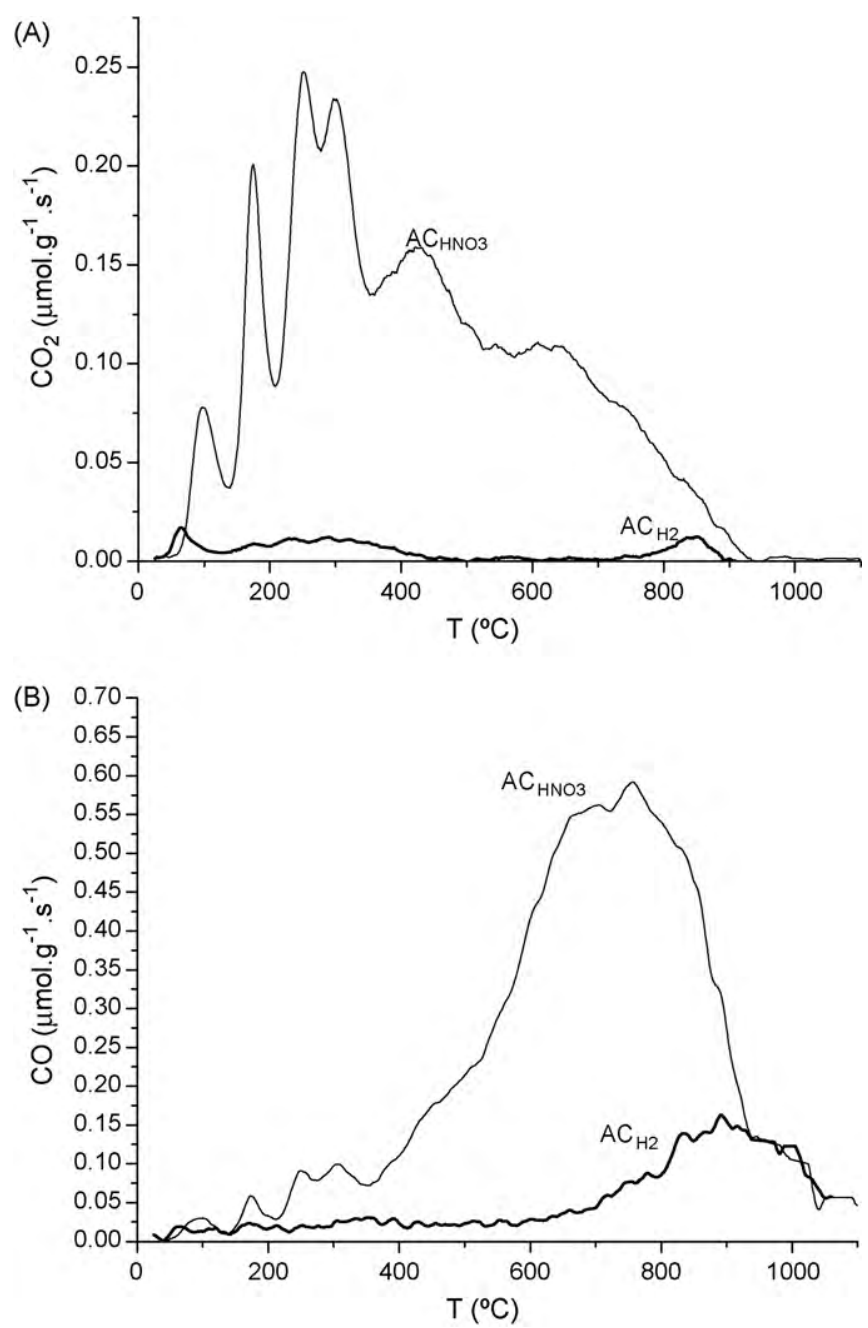

Fig. 2. TPD spectra before and after different treatments: (A) $\mathrm{CO}_{2}$ evolution and (B) $\mathrm{CO}$ evolution. Examples for $\mathrm{AC}_{\mathrm{HNO}_{3}}$ and $\mathrm{AC}_{\mathrm{H}_{2}}$.

basal planes. These electrons are responsible for the high basicity of the thermal treated samples. The acidic oxygen-surface groups have a withdrawal character fixing those $\pi$-electrons [32]. Comparing the two thermal treatments, with $\mathrm{H}_{2}$ more basic materials

Table 3

Oxygen-containing surface groups estimated from the TPD spectra deconvolution $( \pm 10 \%)$.

\begin{tabular}{|c|c|c|c|c|c|}
\hline Sample & $\begin{array}{l}\text { Carboxylic acids } \\
\left(\mu \mathrm{molg}^{-1}\right)\end{array}$ & $\begin{array}{l}\text { Anhydrides } \\
\left(\mu \mathrm{molg}^{-1}\right)\end{array}$ & $\begin{array}{l}\text { Lactones } \\
\left(\mu \mathrm{mol} \mathrm{g}^{-1}\right)\end{array}$ & Phenols ( $\mu \mathrm{molg}^{-1}$ ) & $\begin{array}{l}\text { Carbonyl/quinones } \\
\left(\mu \mathrm{mol} \mathrm{g}^{-1}\right)\end{array}$ \\
\hline $\mathrm{AC}_{0}$ & 110 & 79 & 54 & 428 & 307 \\
\hline $\mathrm{AC}_{\mathrm{HNO}_{3}}$ & 723 & 222 & 158 & 948 & 1232 \\
\hline $\mathrm{AC}_{\mathrm{O}_{2}}$ & 0 & 90 & 149 & 1321 & 2694 \\
\hline $\mathrm{AC}_{\mathrm{N}_{2}}$ & 67 & 15 & 38 & 307 & 568 \\
\hline $\mathrm{AC}_{\mathrm{H}_{2}}$ & 48 & 0 & 11 & 249 & 341 \\
\hline
\end{tabular}



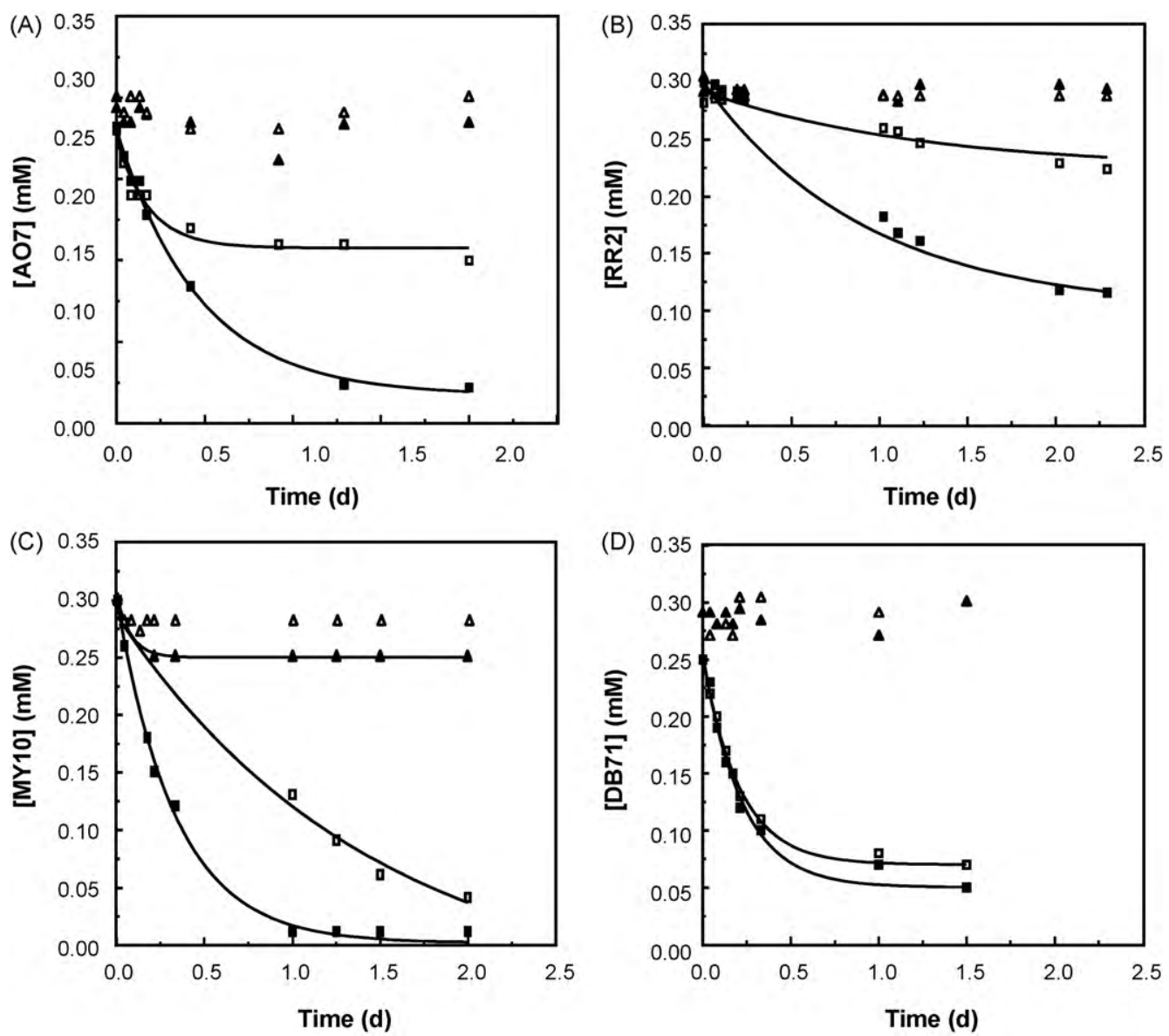

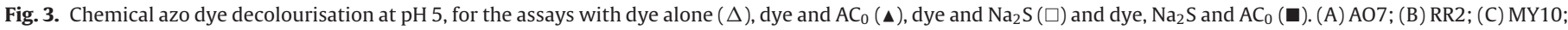
and (D) DB71.

are generated $\left(\mathrm{pH}_{\mathrm{pzc}}\right.$ of 10.8$)$, since a stabilization of the reactive sites by $\mathrm{C}-\mathrm{H}$ bonds occurs [12,32] and also an enhanced effect of the $\pi$-electron system. $\mathrm{N}_{2}$ treatments leave unsaturated carbon atoms that are very reactive for subsequent oxygen adsorption, forming again some of the removed groups upon ambient air exposure. The $\mathrm{pH}_{\mathrm{pzc}}$ of this sample is 9.2 .

\subsection{Azo dye reduction}

Chemical azo dye reduction using sulphide was conducted under anaerobic conditions at $\mathrm{pH}$ values of 5.0, 7.0 and 8.7, both in presence and absence of $\mathrm{AC}_{0}$ (Table 4). Different classes of dyes, acid (AO7), reactive (RR2), mordant (MY10) and direct(DB71), were tested. Decolourisation was followed spectrophotometricaly and a decrease in the intensity of the maximum absorption band was observed for all the dyes, indicating the cleavage of the aromatic azo groups (data not shown), generally related to the formation of lower molecular weight aromatic amines that may be more susceptive to degradation under biological aerobic conditions. The spectra of DB71 shifted from 590 to $550 \mathrm{~nm}$ and the solution changed from blue to light violet colour. All the reactions followed a first-order kinetic model (Fig. 3, example for $\mathrm{pH} 5$ ) and the apparent rate constants and degrees of colour removal were calculated from the initial slope of the concentration vs. time data (Table 4). Undoubtedly, the $\mathrm{pH}$ of dye solution played an important role in the dye reduction. In the assays without AC, only DB71 was reduced at the three tested $\mathrm{pH}$, but the rate was circa 3-fold higher at $\mathrm{pH} 5$ $\left(4.4 \pm 0.6 \mathrm{~d}^{-1}\right)$. The mordant dye was decolourised only at $\mathrm{pH} 5$ and $7,1.1 \pm 0.1$ and $1.4 \pm 0.1 \mathrm{~d}^{-1}$, respectively. AO7 and RR2 were the most resistant to the reduction by sulphide; very low rates were

Table 4

First-order rates $\left(\mathrm{d}^{-1}\right)$ of dye reduction by sulphide, calculated from the reaction at pH 5, 7 and 8.7, in the absence and presence of different AC samples.

\begin{tabular}{|c|c|c|c|c|c|c|c|}
\hline Dye & $\mathrm{pH}$ & No AC & $\mathrm{AC}_{\mathrm{HNO}_{3}}$ & $\mathrm{AC}_{\mathrm{O}_{2}}$ & $\mathrm{AC}_{0}$ & $\mathrm{AC}_{\mathrm{N}_{2}}$ & $\mathrm{AC}_{\mathrm{H}_{2}}$ \\
\hline \multirow[t]{3}{*}{ AO7 } & 5.0 & 0 & $2.2 \pm 0.1$ & $2.4 \pm 0.2$ & $2.6 \pm 0.6$ & $3.0 \pm 0.3$ & $3.4 \pm 0.3$ \\
\hline & 7.0 & $0.2 \pm 0.1$ & $0.7 \pm 0.1$ & $0.6 \pm 0.1$ & $0.5 \pm 0.1$ & $0.8 \pm 0.1$ & $1.2 \pm 0.1$ \\
\hline & 8.7 & 0 & $0.1 \pm 0.1$ & $0.2 \pm 0.1$ & $0.3 \pm 0.1$ & $1.1 \pm 0.2$ & $1.4 \pm 0.2$ \\
\hline \multirow[t]{3}{*}{ RR2 } & 5.0 & $0.9 \pm 0.1$ & $1.3 \pm 0.1$ & $1.2 \pm 0.1$ & $1.2 \pm 0.1$ & $1.3 \pm 0.1$ & $1.2 \pm 0.1$ \\
\hline & 7.0 & 0 & $0.9 \pm 0.1$ & $1.1 \pm 0.1$ & $1.2 \pm 0.1$ & $1.2 \pm 0.1$ & $1.3 \pm 0.1$ \\
\hline & 8.7 & 0 & $0.7 \pm 0.1$ & $0.9 \pm 0.1$ & $0.2 \pm 0.1$ & $0.9 \pm 0.1$ & $1.0 \pm 0.1$ \\
\hline \multirow[t]{3}{*}{ MY10 } & 5.0 & $1.1 \pm 0.1$ & $1.9 \pm 0.3$ & $3.8 \pm 0.2$ & $2.9 \pm 0.2$ & $4.3 \pm 0.6$ & $4.2 \pm 0.4$ \\
\hline & 7.0 & $1.4 \pm 0.1$ & $2.8 \pm 0.2$ & $6.2 \pm 1.1$ & $5.9 \pm 0.1$ & $7.4 \pm 0.7$ & $12.1 \pm 1.3$ \\
\hline & 8.7 & 0 & $2.3 \pm 0.3$ & $2.5 \pm 0.7$ & $0.9 \pm 0.1$ & $2.9 \pm 0.1$ & $4.0 \pm 0.8$ \\
\hline \multirow[t]{3}{*}{ DB71 } & 5.0 & $4.4 \pm 0.6$ & $4.9 \pm 0.2$ & $4.6 \pm 0.1$ & $4.9 \pm 0.2$ & $5.1 \pm 0.2$ & $5.6 \pm 0.3$ \\
\hline & 7.0 & $1.7 \pm 0.3$ & $1.6 \pm 0.2$ & $1.6 \pm 0.1$ & $2.8 \pm 0.4$ & $2.9 \pm 0.6$ & $3.0 \pm 0.1$ \\
\hline & 8.7 & $1.4 \pm 0.1$ & $3.3 \pm 0.1$ & $3.6 \pm 0.1$ & $3.2 \pm 0.3$ & $3.7 \pm 0.2$ & $4.8 \pm 0.3$ \\
\hline
\end{tabular}



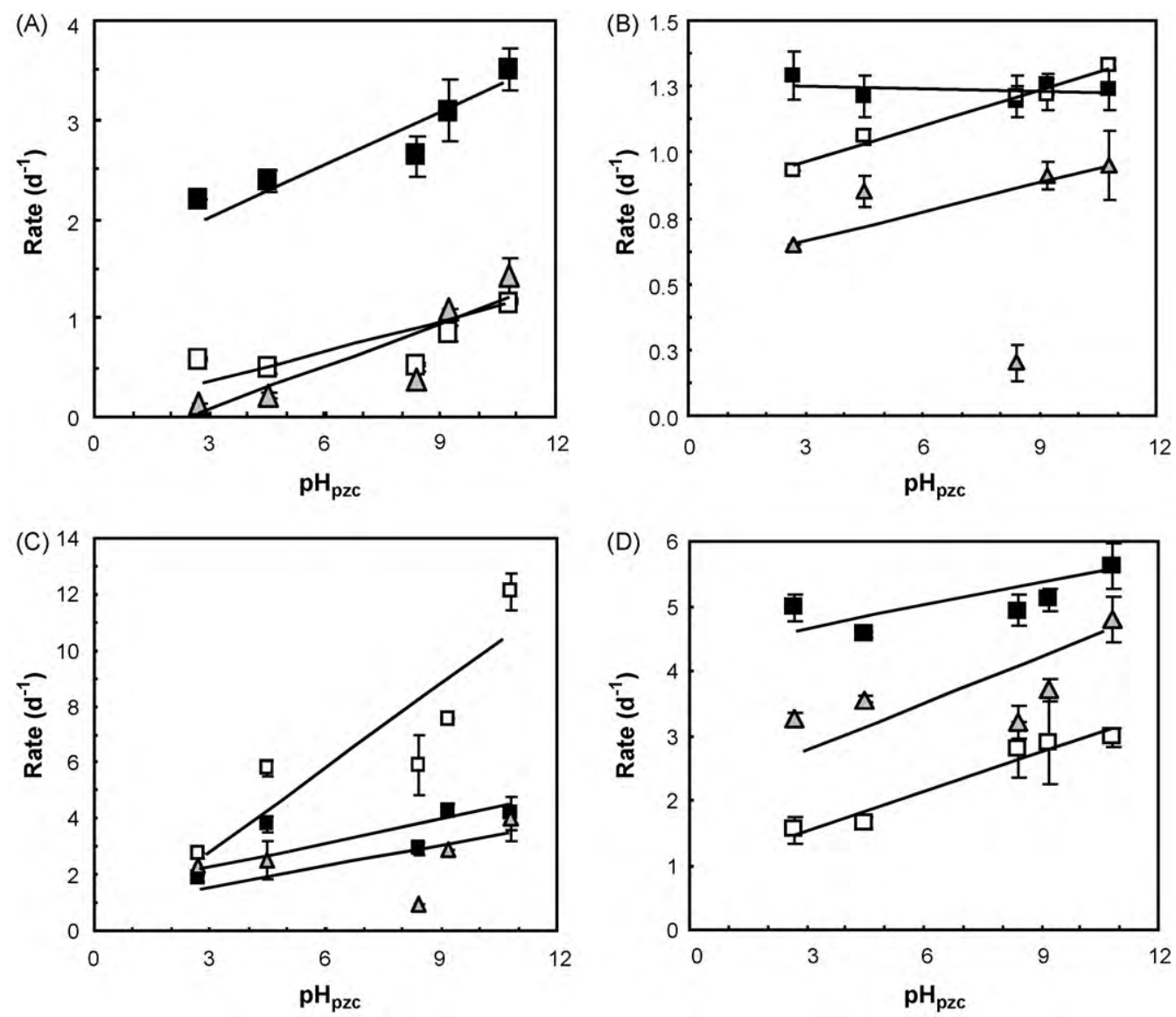

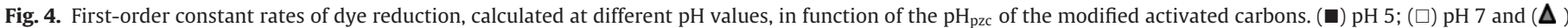
pH 8.7. (A) AO7; (B) RR2; (C) MY10 and (D) DB71.

obtained: $0.2 \pm 0.1 \mathrm{~d}^{-1}$ at $\mathrm{pH} 7$, for $\mathrm{AO} 7$ and $0.9 \pm 0.1 \mathrm{~d}^{-1}$ at $\mathrm{pH} 5$, for RR2. The presence of $A C$ in the reaction solution leads to an improvement of the reduction rates up to 5-fold for AO7, 4-fold for MY10 and 3-fold for DB71. Moreover, the presence of AC turned the decolourisation of all dyes possible at the three $\mathrm{pH}$ tested, with better results under acidic conditions, except for MY10, which was faster decolourised at $\mathrm{pH} 7$ (Table 4). Contrary to the other dyes, for which worse values were calculated under alkaline conditions, no bigger differences were obtained for DB71 in the presence of $\mathrm{AC}_{0}$ at pH $7\left(2.8 \pm 0.4 \mathrm{~d}^{-1}\right)$ and $8.7\left(3.2 \pm 0.3 \mathrm{~d}^{-1}\right)$. Activated carbon samples have amphoteric character and, as a result, their surfaces might be positively or negatively charged depending on the $\mathrm{pH}$ of the solution. Carbon surface becomes positively charged at $\mathrm{pH}<\mathrm{pH}_{\mathrm{pzc}}$ and negatively at $\mathrm{pH}>\mathrm{pH}_{\mathrm{pzc}}$. Because the four tested dyes are anionic, adsorption and the transfer of electrons is more favourable when the carbon surface is positively charged. Negatively charged surface sites on the activated carbon might cause the electrostatic repulsion of the anionic dyes. Therefore, the worst performance at $\mathrm{pH} 8.7$ is expected considering the $\mathrm{pH}_{\mathrm{pzc}}$ of $\mathrm{AC}_{0}$ of 8.4. Similarly, considering the $\mathrm{pH}_{\mathrm{pzc}}$ of all the samples, higher rates at $\mathrm{pH} 5$ than 7 and 8.7 would be expected with samples $\mathrm{AC}_{\mathrm{HNO}_{3}}$ and $\mathrm{AC}_{\mathrm{O}_{2}}$, but not the bigger differences obtained with $\mathrm{AC}_{\mathrm{N}_{2}}$ and $\mathrm{AC}_{\mathrm{H}_{2}}$; however, decolourisation varies also with other parameters such as the molecular structure, $p K_{a}$ and potential redox of the dye, and those have also a dependence on the solution $\mathrm{pH}$. Under optimum conditions, MY10 was almost completely decolourised; the degrees of decolourisation for the other dyes were lower, $80 \%$ for DB71 and $60 \%$ for AO7 and RR2. Colour removal due to adsorption on activated carbon occurs only for the smaller dyes and at low extent: $\sim 25 \%$ for AO7 and 15\% for MY10. Bigger molecules are more dif- ficult to adsorb due to diffusion limitations. These data suggest that the major role of $\mathrm{AC}$ was to enhance the chemical reduction of dye, rather than dye adsorption; the low adsorption degrees are also explained by the little concentration of the catalyst in the solution and the high solubility of the used dyes. AC is the first electron acceptor, being chemically reduced by sulphide and secondly, the electrons from the reduced AC are transferred to the azo dye, the terminal electron acceptor. In previous experiments, chemical reduction of AO7 could also be accelerated by low amounts of AC [10]; with $0.5 \mathrm{mM}$ of sulphide, AO7 removal of $80 \%$ was obtained within 5 days in the presence of AC and only 40\% within 2 weeks in the absence. The amount of AC used was the same as in this study, resulting in similar AO7 adsorption, $22 \%$. In experiments with higher AC concentration, the same reduction results were obtained, but the degree of adsorption increased. In the same study, it was demonstrated that the reduction of RR2 in a lab-scale bioreactor was largely enhanced by AC [10].

\subsection{Effect of AC surface chemical groups on azo dye reduction}

Activated carbon treatments are known to produce significant changes in carbon surface chemistry and these, in turn, can have dramatic effects on the behaviour as adsorbent $[12,14,15]$ and as catalyst [17-21]. We investigated the influence of AC surface chemical groups on its behaviour as a redox mediator for dye reduction by sulphide. As pointed before, dye reduction is also dependent on the $\mathrm{pH}$ of the solution; thus the reaction was carried out at different $\mathrm{pH}$ values, in batch assays. The first-order rates are given in Table 4. A dependence of dye reduction on the type of AC can be observed, with higher rates for the reaction solutions containing 
the most basic activated carbons $\left(\mathrm{AC}_{\mathrm{N}_{2}}\right.$ and $\left.\mathrm{AC}_{\mathrm{H}_{2}}\right)$. These $\mathrm{AC}$ are characterised by a high content of electron rich sites on their basal planes (electrons $\pi$ ) and by a low concentration of electron withdrawing groups. The electrons $\pi$ are the responsible for the better performance as redox mediator, due to the high attainability by the dye. Mezohegyi et al. [24] have also postulated that delocalised $\pi$ electrons seemed to play a role in the catalytic reduction in the absence of surface oxygen.

Fig. 4 represents the dye reduction rates as a function of the $\mathrm{pH}_{\mathrm{pzc}}$ of $\mathrm{AC}$. In general, rates increased with increasing the $\mathrm{pH}_{\mathrm{pzc}}$, following the trend $\mathrm{AC}_{\mathrm{HNO}_{3}}<\mathrm{AC}_{\mathrm{O}_{2}}<\mathrm{AC}_{0}<\mathrm{AC}_{\mathrm{N}_{2}}<\mathrm{AC}_{\mathrm{H}_{2}}$. This behaviour was less pronounced for RR2 reduction, with similar rates at all the conditions. Other deviations are the values for RR2 and MY10 reductions with $\mathrm{AC}_{0}$ at $\mathrm{pH} 8.7$, lower than the calculated with $\mathrm{AC}_{\mathrm{HNO}_{3}}$ and $\mathrm{AC}_{\mathrm{O}_{2}}$. According to the previous sequence, MY10 reduction at pH 5 and 7 with $\mathrm{AC}_{\mathrm{O}_{2}}$ is also higher than the expected; those results may be a consequence of the textural properties alteration due to the burn-off when treating this AC sample. The higher content of quinone groups present in $\mathrm{AC}_{\mathrm{HNO}_{3}}$ and $\mathrm{AC}_{\mathrm{O}_{2}}$ compared to $\mathrm{AC}_{\mathrm{N}_{2}}, \mathrm{AC}_{\mathrm{H}_{2}}$ and the original $\mathrm{AC}$ would have promoted a higher decolourisation rates for the azo dyes studied considering that quinone groups have been proposed as the main electrontransferring groups in AC [10]. Nevertheless, the larger amount of oxygen-containing groups prevailing on the surface of $\mathrm{AC}_{\mathrm{HNO}_{3}}$ and $\mathrm{AC}_{\mathrm{O}_{2}}$, compared to the other $\mathrm{AC}$ samples, also promotes a higher repulsion between the azo dyes and the surface of the these AC, which seems to be the main factor affecting the overall kinetics of the decolourisation process. As with $\mathrm{AC}_{0}$, the adsorption obtained with modified AC samples was also low (maximal of $30 \%$ for $\mathrm{AO7}$ and $18 \%$ for MY10 with $\mathrm{AC}_{\mathrm{H}_{2}}$ ). The low adsorption obtained is expected due to the small AC concentration used, therefore the total dye removal in the chemical assays is mostly due to their reduction. It is worth to mention that high AC concentration limits the process application, due to excessive costs. In their experiments, Mezohegyi et al. [24] have used 5000 times higher AC concentration than in our work. The effect of $\mathrm{pH}$ was also evident on the rates of dye reduction. Except for MY10, which was better degraded at neutral $\mathrm{pH}$, higher rates were obtained at $\mathrm{pH} 5$ with all type of activated carbons. Reactive dye reduction was less influenced by the type of $\mathrm{AC}$ and $\mathrm{pH}$, since similar rates were obtained at all the conditions $\left(\sim 1 \mathrm{~d}^{-1}\right)$, apart from the strange low value with $\mathrm{AC}_{0}$ at $\mathrm{pH} 8.7\left(0.2 \mathrm{~d}^{-1}\right)$. Comparing the four studied dyes, at the optimal conditions, better decolourisation was achieved in order of: MY10 > DB71 > AO7 > RR2. In fact, MY10 was completely reduced within 1 day, at a rate of $12 \pm 1.3 \mathrm{~d}^{-1}$ with $\mathrm{AC}_{\mathrm{H}_{2}}$, being 2 -fold, 4-fold and 9-fold higher than the obtained for the dyes DB71, AO7 and RR2, respectively. Its reduction was the largest improved by the presence of AC, with an increase of 9-fold as compared with the assay without AC. Decolourisation rates are also related with the electron density around the azo bond. Electro withdrawing groups such as $-\mathrm{OH}$ and $-\mathrm{NH}_{2}$ decrease the electron density around the azo bond and facilitate its reduction. A similar effect in a simple reduction of the azo bond is observed for dyes carrying groups such as $-\mathrm{SO}_{3} \mathrm{Na}$ and $-\mathrm{COOH}$ [1]. NH group, on the other hand, are known to demote it [33]. MY10 and DB71 are richer in those first groups and RR2 have the secondary amine on is structure. Triazyl groups, also present in $R R 2$, were found to give low dye reduction rates $[25,26]$, explained by the reducing equivalents required for the reductive dechlorination, which may compete with the azo chromophore. Redox mediators are not only involved in the transfer of reducing equivalents, but also in minimizing the steric hindrance of the dye molecule [6].

\subsection{Biological MY10 reduction}

One of the limitations of biological dye decolourisation is the low rate of the process, which can be overcome by the use of redox
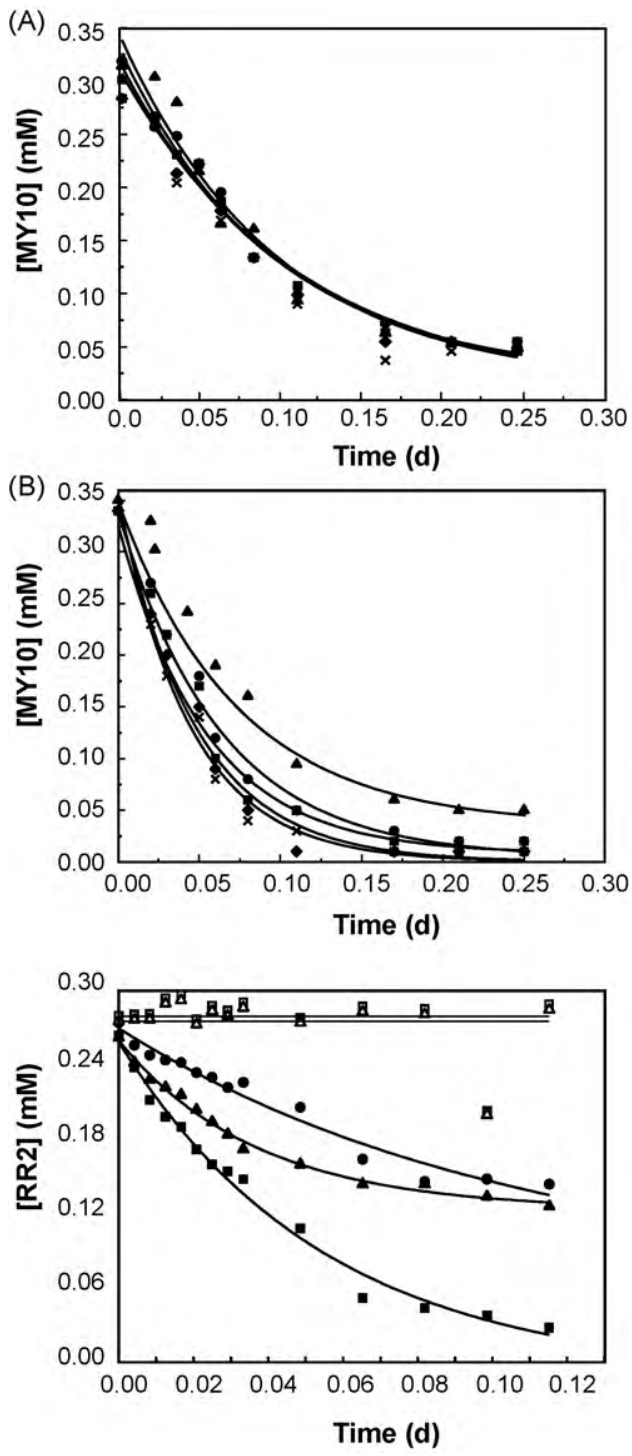

Fig. 5. Biological MY10 and RR2 dye reduction at $\mathrm{pH} 7$ with VFAs as substrate. (A and B) MY10 decolourisation with increasing $\mathrm{AC}$ concentrations $\left(\mathrm{AC}_{0}\right.$ and $\mathrm{AC}_{\mathrm{H}_{2}}$,

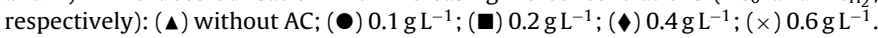
(C) RR2 decolourisation with $0.1 \mathrm{~g} \mathrm{~L}^{-1}$ of $\mathrm{AC}_{0}(\boldsymbol{\Delta})$ and $\mathrm{AC}_{\mathrm{H}_{2}}(\mathbf{\square})$. Control without $\mathrm{AC}$ (•) and without biomass $(\Delta) \mathrm{AC}_{0}$ and $(\square) \mathrm{AC}_{\mathrm{H}_{2}}$.

mediators. The possibility of using AC as mediator in a biological system was investigated by conducting batch experiments with granular biomass. Different substrates were tested in the biological MY10 reduction, in the absence and presence of AC, and 4-fold higher rates were obtained with VFAs (data not shown). Our findings are in agreement with previous studies that investigated the role of various electron donors on the reduction of dyes, concluding that the rates vary with the type of substrate by stimulating specific microorganisms in a mixed culture $[5,8,9]$. Fig. $5 \mathrm{~A}$ and $B$ shows the results of biological MY10 reduction, with VFAs as substrate, in the absence and presence of unmodified $\left(\mathrm{AC}_{0}\right)$ and modified $\left(\mathrm{AC}_{\mathrm{H}_{2}}\right)$ activated carbon. Contrarily to the obtained chemically, MY10 reduction rates in the absence and presence of $\mathrm{AC}_{0}$ were the same, $10.2 \pm 1.4 \mathrm{~d}^{-1}$ (Fig. 5B; Table 5). However, with the thermal treated $\mathrm{AC}\left(\mathrm{AC}_{\mathrm{H}_{2}}\right)$ the decolourisation rate duplicated $\left(19.4 \pm 0.2 \mathrm{~d}^{-1}\right)$. This result shows that, as observed in the chemical assays, AC surface chemistry plays a role in the biological dye decolourisation and that thermal modification of AC improves its capacity as redox mediator. Additionally, different AC amounts 
Table 5

First-order rates $\left(\mathrm{d}^{-1}\right)$ and degree of biological MY10 reduction in the presence of increasing unmodified $\left(\mathrm{AC}_{0}\right)$ and modified $\left(\mathrm{AC}_{\mathrm{H}_{2}}\right)$ activated carbon concentrations.

\begin{tabular}{llrl}
\hline AC sample & {$[\mathrm{AC}]\left(\mathrm{g} \mathrm{L}^{-1}\right)$} & Rate $\left(\mathrm{d}^{-1}\right)$ & Decolourisation $(\%)$ \\
\hline No AC & 0 & $10.2 \pm 1.7$ & $87 \pm 1$ \\
$\mathrm{AC}_{0}$ & 0.1 & $10.2 \pm 1.4$ & $86 \pm 1$ \\
& 0.2 & $9.9 \pm 0.5$ & $85 \pm 1$ \\
& 0.4 & $9.8 \pm 2.2$ & $83 \pm 2$ \\
$\mathrm{AC}_{\mathrm{H}_{2}}$ & 0.6 & $11.3 \pm 1.2$ & $78 \pm 1$ \\
& 0.1 & $19.4 \pm 0.2$ & $87 \pm 1$ \\
& 0.2 & $18.7 \pm 1.3$ & $90 \pm 1$ \\
& 0.4 & $23.6 \pm 3.8$ & $88 \pm 0$ \\
& 0.6 & $19.6 \pm 1.5$ & $89 \pm 1$ \\
\hline
\end{tabular}

were tested and it was found that increasing concentrations from $0.1 \mathrm{~g} \mathrm{~L}^{-1}$ to $0.6 \mathrm{~g} \mathrm{~L}^{-1}$ lead to an increase of the dye adsorption (from $10 \%$ to $65 \%$ not shown) but the reduction rates were similar with untreated and treated AC (Fig. 5A and B; Table 5). This finding is of great importance once activated carbon is costly and therefore the use of low amounts is an advantage for biological processes application.

Furthermore, as a redox mediator, AC is cycled from its oxidised and reduced states and thus should be very effect at low concentrations. Biological reduction of RR2 with untreated $\mathrm{AC}_{0}$ and thermally treated $\mathrm{AC}_{\mathrm{H}_{2}}$ was also studied. With this dye, previously found as a more recalcitrant one, untreated $\mathrm{AC}$ could increase 3-fold the rate of decolourisation (Fig. 5C). Once more, thermal treated AC reveals to be more effective, increasing 4.5 -fold the dye reduction rate.

\section{Conclusions}

The results obtained in the present work demonstrate the catalytic effect, on azo dyes reduction rates, of activated carbon with different surface chemistry, obtained by chemical or thermal treatments. Dye reduction rates increased up to 9-fold using an AC concentration of $0.1 \mathrm{~g} \mathrm{~L}^{-1}$, as compared with an assay not amended with AC. Amongst the four dyes tested, MY10, AO7, RR2 and DB71, better results were obtained at $\mathrm{pH} 5$, except for MY10, with higher rates determined at $\mathrm{pH} 7$. AC performance as a catalyst was, in this case, improved by surface modification, applying thermal treatments. In order to be an effective redox mediator for anionic dyes, the carbon should have a high $\mathrm{pH}_{\mathrm{pzc}}$. This means that at $\mathrm{pH}$ lower than $\mathrm{pH}_{\mathrm{pzc}}$, the carbon will be positively charged, favouring electrostatic attraction between the carbon and the anionic dyes tested. Reduction rates increased with the activated carbon basicity as following: $\mathrm{AC}_{\mathrm{HNO}_{3}}<\mathrm{AC}_{\mathrm{O}_{2}}<\mathrm{AC}_{0}<\mathrm{AC}_{\mathrm{N}_{2}}<\mathrm{AC}_{\mathrm{H}_{2}}$. Dye reduction rates in the presence of $A C$ also varied among the different dyes. Higher rates were obtained in order of: MY10 > DB71 > AO7 > RR2. Dye reduction by sulphide in the absence of $A C$ was very limited, since only DB71 was reduced at the three $\mathrm{pH}$ tested and MY10 at pH 5 and 7. AO7 and RR2 were more resistant to chemical reduction. We have also demonstrated that surface modified $\mathrm{AC}_{\mathrm{H}_{2}}$ could duplicate and increased 4.5-fold the rates of MY10 and RR2 decolourisation, respectively, in a biological assay which was independent of the AC concentration in the tested range of $0.1-0.6 \mathrm{~g} \mathrm{~L}^{-1}$. As AC can be retained in a reactor for prolonged time, it is an attractive alternative to soluble redox mediators in a biological reactor system. The low amount of AC used in this work and the positive results demonstrated for chemical and biological catalysis constitutes a significant breakthrough in the field of redoxmediated processes which will certainly open new perspectives for wastewater treatment processes of several xenobiotics.

\section{Acknowledgements}

This work was supported by the PTDC/AMB/69335/2006 project grants. L. Pereira holds a Pos-Doc fellowship (SFRH/BPD/20744/
2004) and R. Pereira holds a fellowship (SFRH/BPD/39086/2007) from Fundação para a Ciência e Tecnologia. F.J. Cervantes greatly acknowledges a grant from Council of Science and Technology of Mexico (Grant SEP-CONACYT-C02-55045).

\section{References}

[1] H. Chen, Recent advances in azo dye degrading enzyme research, Curr. Protein Pept. Sci. 7 (2006) 101-111.

[2] T. Robinson, G. McMullan, R. Marchant, P. Nigam, Remediation of dyes in textile effluent on current treatment technologies with a proposed alternative, Bioresour. Technol. 77 (2001) 247-255.

[3] A. Stolz, Basic and applied aspects in the microbial degradation of azo dyes, Appl. Microbiol. Biotechnol. 56 (2001) 69-80.

[4] R. Russ, J. Rau, A. Stolz, The function of cytoplasmatic flavin reductases in the reduction of azo dyes by bacteria, Appl. Environ. Microbiol. 66 (2000) 1429-1434.

[5] A.B. dos Santos, F.J. Cervantes, R.E. Yaya-Beas, J.B. van Lier, Effect of redox mediator, AQDS, on the decolourisation of a reactive azo dye containing triazine group in a thermophilic anaerobic EGSB reactor, Enzyme Microb. Technol. 33 (2003) 942-951.

[6] A.B. dos Santos, I.A.E. Bisschops, F.J. Cervantes, J.B. van Lier, Effect of different redox mediators during thermophilic azo dye reduction by anaerobic granular sludge and comparative study between mesophilic $\left(30^{\circ} \mathrm{C}\right)$ and thermophilic $\left(55^{\circ} \mathrm{C}\right)$ treatments for decolourisation of textile wastewaters, Chemosphere 55 (2004) 1149-1157.

[7] F.J. Cervantes, F.P. Van der Zee, G. Lettinga, J.A. Field, Enhanced decolourisation of acid orange 7 in a continuous UASB reactor with quinines as redox mediators, Water. Sci. Technol. 44 (2001) 123-128.

[8] F.P. Van der Zee, R.H.M. Bouwman, D.P.B.T.B. Strik, G. Lettinga, J.A. Field, Application of redox mediators to accelerate the transformation of reactive azo dyes in anaerobic bioreactors, Biotechnol. Bioeng. 75 (2001) 691-701.

[9] F.P. Van der Zee, F.J. Cervantes, Impact and application of electron shuttles on the redox (bio)transformation of contaminants: a review, Biotechnol. Adv. 27 (2009) 256-277.

[10] F.P. Van der Zee, I.A. Bisschops, G. Lettinga, J.A. Field, Activated carbon as an electron acceptor and redox mediator during the anaerobic biotransformation of azo dyes, Environ. Sci. Technol. 37 (2003) 402-408.

[11] G. Mezohegyi, A. Kolodkin, U.I. Castro, C. Bengoa, F. Stuber, J. Font, A. Fabregat, Effective anaerobic decolorization of azo dye acid orange 7 in continuous upflow packed-bed reactor using biological activated carbon system, Ind. Eng. Chem. Res. 46 (2007) 6788-6792.

[12] M.F.R. Pereira, S.F. Soares, J.J.M. Órfão, J.L. Figueiredo, A desorption of dyes on activated carbons: influence of surface chemical groups, Carbon 41 (2003) 811-821.

[13] P.K. Malik, Dye removal from wastewater using activated carbon developed from sawdust: adsorption equilibrium and kinetics, J. Hazard. Mater. B 113 (2004) 81-88

[14] P.C.C. Faria, J.J.M. Orfão, M.F.R. Pereira, Mineralisation of coloured aqueous solutions by ozonation in the presence of activated carbon, Water Res. 39 (2005) 1461-1470.

[15] P.C.C. Faria, J.J.M. Orfão, J.L. Figueiredo, M.F.R. Pereira, Adsorption of aromatic compounds from the biodegradation of azo dyes on activated carbon, Appl. Surf. Sci. 254 (2008) 3497-3503.

[16] Y.S. Al-Degs, M.I. El-Barghouthi, A.H. El-Sheikh, G.M. Walker, Effect of solution $\mathrm{pH}$, ionic strength, and temperature on adsorption behaviour of reactive dyes on activated carbon, Dyes Pigments 77 (2008) 16-23.

[17] M.F.R Pereira, J.J.M. Orfão, J.L. Figueiredo, Oxidative dehydrogenation of ethylbenzene on activated carbon catalysts. I. Influence of surface chemical groups, Appl. Catal. A: Gen. 184 (1999) 153-160.

[18] J. Muñiz, G. Marbán, A.B. Fuertes, Low temperature selective catalytic reduction of NO over modified activated carbon fibres, Appl. Catal. B: Environ. 27 (2000) 27-36.

[19] Z.H.Zhu, L.R. Radovic, G.Q. Lu, Effects of acid treatments of carbon on NO and NO reduction 2 by carbon-supported copper catalysts, Carbon 38 (2000) 451-464.

[20] M.A. Moteleb, M.T. Suidan, J. Kim, J.L. Davel, N.R. Adrian, Anaerobic degradation of 2,4,6-trinitrotoluene in granular activated carbon fluidized bed and batch reactors, Water Sci. Technol. 43 (2001) 67-75.

[21] R. Moliner, I. Suelves, M.J. Lazaro, O. Moreno, Thermocatalytic decomposition of methane over activated carbons: influence of textural properties and surface chemistry, Int. J. Hydrogen Energy 30 (2005) 293-300.

[22] Y. Al-Degs, M.A.M. Khraisheh, S.J. Allen, M.N. Ahmad, Effect of carbon surface chemistry on the removal of reactive dyes from textile effluent, Water. Res. 34 (2000) 927-935.

[23] D.C.W. Tsang, J. Hu, M.Y. Liu, W. Zhang, K.C.K. Lai, I.M.C. Lo, Activated carbon produced from waste wood pallets: adsorption of three classes of dyes, Water Air Soil Pollut. 184 (2007) 141-155.

[24] G. Mezohegyi, F. Gonçalves, J.J.M. Órfão, A. Fabregat, A. Fortuny, J. Font, C Bengoa, F. Stuber, Tailored activated carbons as catalysts in biodegradation of textile azo dyes, Appl. Catal. B: Environ. 94 (2010) 179-185.

[25] F.P. Van der Zee, G. Lettinga, J.A. Field, Azo dye decolourisation by anaerobic granular sludge, Chemosphere 44 (2001) 1169-1176.

[26] F.J. Cervantes, J.E. Enríquez, E. Galindo-Petatán, H. Arvayo, E. Razo-Flores, J.A. Field, Biogenic sulphide plays a major role on the riboflavin-mediated 
decolourisation of azo dyes under sulphate-reducing conditions, Chemosphere 68 (2007) 1082-1089.

[27] J.L. Figueiredo, M.F.R. Pereira, M.M.A. Freitas, J.J.M. Orfão, Modification of the surface chemistry of activated carbons, Carbon 37 (1999) 1379-1389.

[28] F. Rodriguez-Reinoso, J.M. Martin-Martinez, C. Prado-Burguete, B. McEnaney, A standard adsorption isotherm for the characterization of activated carbons, J. Phys. Chem. 91 (1987) 515-516.

[29] A. Linares-Solano, in: J.L. Figueiredo, J.A. Moulijn (Eds.), Carbon and Coal Gasification, Martinus Nijhoff Publishers, Dordrecht, The Netherlands, 1986, pp. 137-178.
[30] H.F. Stoeckli, L. Ballerini, S. De Bernardini, On the evolution of micropore widths and areas in the course of activation, Carbon 27 (1989) 501-502.

[31] J.L. Figueiredo, M.F.R. Pereira, M.M.A. Freitas, J.J.M. Orfão, Characterization of active sites on carbon catalysts, Ind. Eng. Chem. Res. 46 (2007) 4110-4115.

[32] J.A. Menéndez, J. Phillips, B. Xia, L.R. Radovic, On the modification and characterization of chemical surface properties of activated carbon: in the search of carbons with stable basic properties, Langmuir 12 (1996) 4404-4410.

[33] Z. Shen, W. Wang, J. Jia, J. Ye, X. Feng, A. Peng, Degradation of dye solution by an activated carbon fibre electrode electrolysis system, J. Hazard. Mater. B 84 (2001) 107-116. 